\title{
EFFECT OF INTERNAL CONTROL ON EXECUTION OF CAPITAL PROJECT IN NIGERIA: EVIDENCE FROM ANAMBRA STATE PUBLIC SECTOR
}

\author{
Ezejiofor, Raymond A. \\ Department of Accountancy \\ Nnamdi Azikiwe University, Awka \\ Mail: thaddray4life@yahoo.com \\ Ebubechukwu, Jacinta O. \\ Department of Accountancy \\ Federal Polytechnic, Nekede \\ Mail: ogo4ebube2010@gmail.com \\ Ndum, Ngozi Blessing \\ Department of Accountancy \\ Nnamdi Azikiwe University, Awka \\ Mail: ngodona71@gmail.com
}

\begin{abstract}
This study ascertained the effect of internal control on the execution of capital projects in Anambra States, Nigeria. The study adopted survey research design. A sample of 118 Auditors and Accountants and staff of various Ministries and Departments in Anambra State. The formulated hypotheses were tested using regression analysis. The regression result shows that personnel control (PSC) has a positive and significant effect on the capital project execution in the state. The regression result also shows that management control (MGC) has a positive but insignificant effect on the capital project execution in Anambra state, Nigeria. It therefore recommends that, management control execution should be strengthened up in such regions as these were found to be positively and significantly affecting the rate of capital project execution in the state. Also Public sectors in the state, as well, the use internal control system to minimize the level of the neglected project in the state should be considered.
\end{abstract}

Keywords: Internal Control, Capital Project Execution, Personnel Control, and Management Control 


\section{Introduction}

Internal control is a broad concept that covers the entire range of procedures, methods and controls established by an organization to increase the probability to achieve its business goals (Institute of Internal Auditors (IIA), 2012). Also, internal control can be seen as a group of policies and procedures that are embedded to form control on a firm's activities to ensure the entity followed objectives set by management and the board of directors (Yousef, 2017).

Control is an authority, charge, or power given to someone to affect or guide another person or thing (Ofor, 2019). In other words, an individual, family, business entity, enterprise, organization, society as well as a nation, can be controlled. Control can come from either internal sources or external sources. When control comes from internal source, it is called internal control and when it comes from external sources, it is known as external control. In any type of organization, one form of control or the other is exercised by the organisation, irrespective of the organization's size, type and nature and such control becomes an internal control when it is established by the management of such an organization. Therefore, internal control as the name involves the various rules, regulations, and policies established by management to assist them in checking, regulating and directing the activities of such an organization in other to achieve the organization's set goals and objectives.

Nigerian government has engaged in reforms and campaigns like National Economic Empowerment Development Strategy (NEEDS) with the sole aim of improving the Nigerian economy, yet there is a high rate of unaccomplished capital project strategies, resulting in capital project mismanagement and abandonment, despite these reforms introduced in the system. Countless kilometers of road, many fine factories and hundreds of projects exist only as dreams in Nigeria despite years of promises (Simon, 2012). From the report of Presidential Project Assessment Committee (PPAC) released recently, that there are eleven thousand, eight hundred and eighty- six $(11,886)$ abandoned projects that will cost an estimated $\$ 7.78$ trillion to either complete them or if the government does not start any new projects, it will take more than five years budgeting, about 1.5 trillion annually to complete them all (El- Rufai, 2012). This made Simon (2012) to maintain that control over project management in Nigeria should improve to reduce the problem of abandonment and wastages of public funds. Oyewobi Ganiyu, Oke, Olaawo and Shittu (2011) argue that the regulatory oversight has not kept pace with internal control development in the Nigerian public sector despite the enactment of the Public Procurement Act No.14, 2007, Law of the Federation of Nigeria. In addition to that, Simon (2012); Ingwe, Mboto, and Ebong (2012) thought that project abandonment increased in Nigeria due to incessant policy discontinuities and politicians have questionable discretion in awarding contracts without following due process.

Studies had reported that capital project relinquishment in some states led to various factors such as inadequate funding, pre-contract calamities and shortfall in project management. This can result in the issues of awarding contracts without following due process, policy gaps and politicians uncertain discretion in awarding contracts. However, none these studies have considered the effect of internal control systems on the rate of project execution in Anambra state. This study thereby assesses the effect of internal control systems on project execution in Anambra State public sector. Specifically, the study intends to:

1. Ascertain the effect of personnel control on the project execution in Anambra States, Nigeria. 
2. Determine the effect of management control on the project's execution in Anambra States, Nigeria.

\section{Review of Related Literature}

\section{Internal Control}

Internal control has been defined by different people in different ways but the most popular definition of internal control system is the definition given by Auditing Standards and Guidelines as they define Internal Control system " as the whole system of controls, financial and otherwise, established by management in order to carry on the business of the enterprise in an orderly and efficient manner, ensure adherence to management policies, safeguard the assets and secure as far as possible the completeness and accuracy of the records".

Committee of Sponsoring Organizations (COSO) of the Tread way Commission (1992) also gives a more internationally acceptable definition of internal control as they define internal control as "a process, effected by an entity's management and other personnel, designed to provide reasonable assurance regarding the achievement of objectives in the following categories: (i) Effectiveness and efficiency of operations; (ii) Reliability of financial reporting; and (iii) Compliance with laws and regulations". Ingram (2009) also defines internal controls as "systems and procedures designed by management to ensure that all employees perform their duties ethically and honestly". An alternative definition was given by Benjamin (2001) as "the whole system of control, financial and otherwise, established by management in order to carry on the business of the enterprises in an orderly and efficient manner".

Every internal control system whether in the public or private sector is made up of different components or integrated frameworks of networks. These components are those procedures and methods which the management of an entity adopts to aid them achieve their objectives of ensuring that the business of the entity is properly conducted in an orderly and efficient manner. It also ensures prevention and detection of fraud and errors, security of assets, accuracy of the accounting system and the timely preparation of reliable financial information. The Basle Committee (1998), along with banking supervisors throughout the world, has focused increasingly on the importance of sound internal controls. This heightened interest in internal controls is, in part, a result of significant losses incurred by several banking organizations. An analysis of the problems related to these losses indicates that they could probably have been avoided had the banks maintained effective internal control systems. Such systems would have prevented or enabled earlier detection of the problems that led to the losses, thereby limiting damage to the banking organization. In developing these principles, the Committee has drawn on lessons learned from problem bank situations in individual member countries.

\section{Personnel Control}

This is the type of control that ensures the recruitment of accurate and competent employees as well as employee monitoring activities that will lead to the attainment of organizational goals and objectives (Ofor, 2019). It is the part of internal control that involves the appointment of competent and motivated staff to carry out the assignment of an organisation. 
However, ENSG Internal Control Manual (2010) stipulates that the major elements under these controls include:

i. Ethical values and integrity controls.

ii. Controls to ensure the competence of employees

iii. Controls to ensure that senior public servants lead by example

iv. Organizational structure controls.

Personnel management aim to assure that an enterprise has the right staff, with the right qualifications, at the right cost structure levels, and that they are in the right place at the right time. The task of Personnel Controlling is this process: to manage and track (i.e. measure). At the same time, Personnel Controlling functions as an early-warning system drawing attention to deviations between the set aims and reality. Personnel Controlling at the same, may contribute towards the evaluation of the intangible activities of an enterprise (through the intermediary of human capital values), and which create an ever-larger part of an enterprise's value (Zámečník \& Zeman, 2007).

\section{Management Control}

According to Ofor (2019), these are controls exercised by management that are over and above the day-to-day routine of the system. Management control consists of overall supervisory controls, review of management accounts, and comparison with budgets, internal audit and any other special review procedures. Examples of management control are;(i) Senior management staff briefing on the day-to-day activities of the organization to identify areas of weakness in the internal control instituted by the organization such as stock theft, excess stocking, unnecessary overtime, etc.(ii) Management accounts designed to summarize performance.(iii) Budgeting and variance analysis done by the management. This is a management tool that prevents or helps to detect departure from the management plans (iv) Acknowledgement of Performance: Staff performing on assignment should be acknowledged their activities through signature, initials, rubber stamps, etc.

However, according to Abugri (2015), internal controls of every organization remain one of the strategic tools for improving corporate governance and financial management administration for the public sector is not an exception, especially in the face of limited resources of a country that adopted the Economic Recovery Programme (ERP) in April 1983, followed by the Structural Adjustment Programme (SAP) in August 1986 and HIPIC Initiative in 2002 to salvage the ailing Ghanaian economy.

In the private sectors, for example, Basle Committee (1998) maintained that for effective management control to be achieved in banks, the board of directors should have responsibility for approving and periodically reviewing the overall business strategies and significant policies of the bank; understanding the major risks run by the bank, setting acceptable levels for these risks and ensuring that senior management takes the steps necessary to identify, measure, monitor and control these risks; approving the organizational structure; and ensuring that senior management is monitoring the effectiveness of the internal control system. The board of directors is ultimately responsible for ensuring that an adequate and effective system of internal controls is established and maintained. Senior management should have responsibility for implementing strategies and policies approved by the board; 
developing processes that identify, measure, monitor and control risks incurred by the bank; maintaining an organizational structure that assigns responsibility, authority and reporting relationships; ensuring that delegated responsibilities are effectively carried out; setting appropriate internal control policies; and monitoring the adequacy and effectiveness of the internal control system. These functions should also apply to the public sector for management controls to be achieved.

\section{Project Execution Rate}

An effective internal control system requires that the material risks that could adversely affect the achievement of the Ministry's goals in the public sector should be recognized and continually assessed. This assessment should cover all risks facing the sector and the consolidated Ministries operations (that is, credit risk, country and transfer risk, market risk, interest rate risk, liquidity risk, operational risk, legal risk and reputational risk). Internal controls may need to be revised to appropriately address any new or previously uncontrolled risks.

The strategic importance of capital projects as an economic development driver cannot be over-emphasized. Its potential attributes are numerous. It serves as a catalyst to public development in all the agenda of government such as health care delivery, roads and transportation, education, security, energy and shelter. Therefore, capital project management gives an impetus to the development ratings of a nation. Nwachuckwu and Emoh (2011) argue that capital project management cuts across human endeavour from various fields of life such as government and agents of government like members of the State' s tenders' board and procurement officers. Oyewobi et al. (2011) found that there exists a relationship between internal control and project activities. "project cost control effectiveness will be impacted by how well the basic project management practices are implemented on the project, including the definition of such items as governance, roles and responsibilities" (Basak, 2010).

According to delayed (Ofor, 2019) abandoned project is a project which has been totally abandoned, or indefinitely Abandonment may happen at any stage of a project lifecycle and incur a significant amount of loss. Prior studies have shown that non-functional government policies, defective procurement procedures, corruption, incompetent Builders (contractors), death of the client, defective design or inappropriate change in design, inadequate planning can contribute significantly to project abandonment. Specifically, a study conducted by Olalusi and Otunola (2012) revealed that incorrect estimation, insufficient planning, lack of risk management know-how, dearth of skilled personnel, poor knowledge of the work requirement as well as corruption are some of the key reasons for the failure of public projects in Nigeria.

\section{Empirical Review}

Many studies have been done in the past as regards internal control system in the public sector, for example, in a study done by Salifu (2015) ascertained the internal control systems of public institutions in Ghana, using Tamale Polytechnic, discovered that there are the existence of strict supervision, authorization and segregation of duties in Ghana public sector. The study also revealed that control systems at the Polytechnic are quite effective and are directed towards the detection and prevention of fraud and errors in the institution. Salihu (2015) determined the effect of internal audit on internal controls effectiveness in tertiary 
institutions in Adamawa State and found that the components of internal control systems are not properly implemented by the management of the institution especially in the areas of authorization and approval, supervision, segregation of duties and personnel controls. Ezejiofor and Okolocha (2020) assessed the internal audit function on financial performance of commercial banks in Enugu State, Nigeria. Survey research design was adopted. The population of the study consists of seven (7) branches each from five (5) selected commercial banks in Enugu metropolis, Enugu State of Nigeria, which comprises of managers, internal control officers, fund transfer officers, and cash officers. The hypotheses were tested using a simple regression statistical tool with aid of SPSS version 20.0 at $5 \%$ level of significance. The study found that internal audit control and procedures have a positive effect on the financial performance of commercial banks in Nigeria and this effect is statistically significant at 5\% level of significance. Ofor (2019) studied the effective implementation rate of internal control systems in both public and private sectors, using a sample size of 200 respondents drawn from both private and public sectors and the result shows that accounting control, administrative and operational control, personnel control and management controls are more effectively implemented in the private sector in Nigeria than the public sector. Oraka, Erhirhie and Ezejiofor (2018) examined the social and environmental auditing on sustainable development in Nigeria. A survey research design was adopted. Data were obtained from questionnaires and analyzed with five points Likert scale and the three hypotheses formulated were tested using t-test statistical tool with the aid of SPSS statistical package version 20.0. It was found that social and environmental auditing enhanced in determining the perception of society toward business organizations in the Nigerian economy. Another finding is that the level of adoption of social and environmental auditing has influence on the operations of the business organization in the Nigerian economy. Babatunde and Dandago (2014) analyzed internal control system deficiency and capital project mismanagement in the Nigerian public sector, A sample of two hundred and twenty eight capital projects (228) was used. Kendall's tau_b t, ANOVA and Chi-square X 2 statistics were employed for analyzing the data collected. This study finds that internal control system deficiency has significant negative effects on capital project management in the Nigerian Public Sector. Eniola and Akinselure (2016) evaluated the effectiveness of internal control systems on financial performance of firms in Nigeria. The study is based on survey research approach. The statistical data used for the study were obtained by the distribution of one hundred and fifty (150) questionnaires among selected employees, in the five (5) organizations considered in this research work. These respondents were selected using the non-probability sampling method, the data obtained from the questionnaire were analysed using multiple regression statistical tools in SPSS (Statistical packages for social sciences). The result of the analysis shows that internal control has significant relationship with fraud perpetrated in the organization, and this was because the P-value obtained (i.e.0.002) using multiple regressions was greater than the benchmark value of 5\% specified in SPSS for this analysis. Frazer (2018) in his own study investigated the effect of internal control systems on deviation in small restaurants. The data was analyzed using multiple regression and descriptive statistics. The results from this study indicated that there was a statistically significant relationship between internal control and deviation (i.e., errors, fraud and waste). Participants also perceived their establishments' internal control activities quality to be lacking when compared to the Committee of Sponsoring Organizations of the Tread way Commission's (COSO) internal control integrated framework. The findings of this study have the prospect to support strategic objectives and best practices of restaurants. Kabuye (2019) examined the contribution made by the internal control systems and working capital 
management on financial performance of supermarkets. This study is cross-sectional and correlational, and it uses firm-level data that were collected using questionnaire survey from a sample of 110 supermarkets in Uganda. Results suggest that working capital management is a significant predictor of financial performance. Contrary to previous thinking internal control systems do not significantly predict financial performance. Therefore, once organizations have appropriate working capital management, they are also likely to have adequate internal control systems that enhance financial performance. The results are important for internal control and working capital policy development, for example, in terms of prescribing the internal control systems and working capital requirements for the organizations to enhance financial performance. Internal control systems and working capital management have apparently hitherto been the subject of limited consideration by most supermarkets in Uganda. Nevertheless, this study, in possibly the most thorough treatment so far, highlights the areas requiring improvement to enhance financial performance. Umaru and Umar (2018) examined the effect of internal control systems on the performance of commercial banks in Nigeria. A survey method was employed and the study used stratified random sampling, in which a total of 382 questionnaires were administered to either staff of operations, marketing, or security department in the Nigerian commercial banks. The questionnaire is a 5 point Likert-scale while the data collected was analyzed using Statistical Package for the Social Sciences (SPSS) version 23 (v23) and Smart PLS 3. The findings of the study revealed that there is a positive and significant relationship between the four components of internal control (control environment, control activities, monitoring and risk assessment) and bank performance. Muhunyo (2018) determined the effect of internal control systems on financial performance in public institutions of higher learning in Nairobi City County. The study used a descriptive research design. This study took a sample study approach with its target population being the different categories of staff in different departments of Public Institutions of Higher Learning in Nairobi City County, Kenya. Descriptive statistics was used in the data analysis and information presented in statistical forms. Linear regression was also used to analyze the relationship between the dependent and independent variables. The study realized that the control environment, risk assessment, control activities and information and communication as indicators of internal control systems have a significant influence on the financial performance of the institutions of higher learning in Nairobi City County, Kenya.

Scholars have made some achievements in the area of the internal control systems in public sector both within and outside Nigeria. For Instance, most studies conducted in Nigeria show that some internal control systems are weak, inadequate or not complied to in the public sector. The study pointed out that it is obvious that the act of fraud has become the order of the day in the public sectors in Nigeria due to inefficient management culture on fraud which indicates absence of internal control system in public sectors in Nigeria. However, none these studies have considered the effect of internal control systems on the rate of project execution in Anambra state. This study thereby assesses the effect of internal control systems on project execution in public sector in Anambra State, Nigeria.

\section{Methodology}

The research design adopted for this study is survey design. According to Asika (2008) survey design is an efficient and systematic way of collecting data based on individual opinion from a broad spectrum setting like a public sector organization. This research focused 
on Anambra State government. Also, the State is a large employer of public servants such as accountants and auditors, due to large number of commercial activities in the State.

This study used ten out of nineteen ministries in the State for this study, in which the researchers used simple random sampling to select these ministries. Thus, since the researchers does not want to study the entire population. A total of 118 the numbers of questionnaires were distributed in the State. But 98 of these questionnaires were completed and return by the respondents.

The study employed regression analysis with the aid of E-view 9.0, to ascertain the relationship among the variables,

\section{Model Specification}

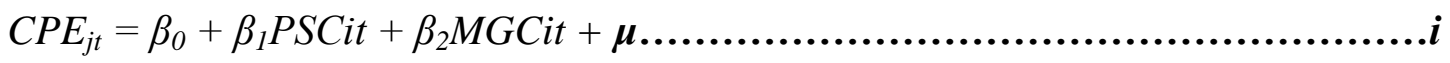

Where :

$\mathrm{CPE}=$ Capital Project Execution Rate (Dependent variable)

$\mathrm{PSC}=$ Personnel control

MGC $=$ Management control variables'

$\beta_{0}$ is the constant term; $\beta_{0}$ and $\beta_{2}$ represents the coefficients of our independent $\mu$ is the error term.

\section{Decision Rule:}

Accept $\mathrm{H}_{0}$ if $\mathrm{P}$-value is > than 10; Otherwise reject $\mathrm{H}_{0}$, to accept $\mathrm{H}_{1}$

\section{Analysis of Data}

\section{Test of Hypotheses}

However, to examine the effect relationships between the dependent variables (CPE) and the independent variables (PSC and MGC) and to also test our formulated hypotheses, the study used and regression analysis. The panel interaction based regression results obtained is presented and discussed below while detailed result. 


\section{Table 1: CPE Regression Model}

Dependent Variable: CPE

Method: Least Squares

Date: 03/25/21 Time: 11:11

Sample: 20082019

Included observations: 12

\begin{tabular}{lrlrr}
\hline \hline \multicolumn{1}{c}{ Variable } & Coefficient & \multicolumn{1}{c}{ Std. Error } & t-Statistic & Prob. \\
\hline \hline C & 0.071754 & 0.714315 & 0.100452 & 0.9202 \\
MGC & 0.017450 & 0.378892 & 2.685333 & 0.0083 \\
\multicolumn{1}{c}{0.028587} & 0.165101 & 0.173148 & 0.8628 \\
\hline \hline R-squared & 0.459828 & Mean dependent var & 0.493763 \\
Adjusted R-squared & 0.435721 & S.D. dependent var & 0.845262 \\
S.E. of regression & 0.830028 & Akaike info criterion & 2.497783 \\
Sum squared resid & 80.60664 & Schwarz criterion & 2.590206 \\
Log likelihood & -147.1159 & Hannan-Quinn criter. & 2.535320 \\
F-statistic & 12.81784 & Durbin-Watson stat & 1.012088 \\
Prob(F-statistic) & 0.000000 & & \\
\hline \hline
\end{tabular}

E-Views 9.0 output, 2021

Table 1, observed that that the R-squared and adjusted R-squared values were 0.460 and 0.436 respectively. This indicates that all the independent variables jointly explain about $46 \%$ of the systematic variations in CPE in public sector in the State.

Test of Autocorrelation: Using Durbin Watson (DW) statistics which we obtained from the regression result in table 1, observed that DW statistic is 1.012 which is approximately 1 , agrees with the Durbin Watson rule of thumb. Showing that our data is free from autocorrelation problem and as such fit for the regression result to be interpreted and result relied on. Akika Info Criterion and Schwarz Criterion which are 2.498 and 2.590 respectively, further strengthen the fitness of our regression result for reliability as they confirm the goodness of fit of the model specified. Adding to the above, the findings from each variable are as follows:

Personnel Control (PSC) and Capital Project Execution (CPE), based on the t-statistics value of 2.685333 and p-value of 0.001 was found to have a positive effect on capital project execution in Anambra State, Nigeria. This influence is statistically significant since its pvalues are less than 5\%. We therefore, accept alternative hypothesis one $\left(\mathrm{H}_{\mathrm{I}}\right)$ which state that personnel control significantly affect the capital projects execution in public sector in Anambra State, Nigeria.

Management Control (MGC) and Capital Project Execution (CPE), shows that tstatistics value of 0.173148 and p-value of 0.863 was found to have a positive effect on capital project execution in Anambra State, Nigeria but this effect is not statistically significant at $5 \%$ level since its p-values is higher than 0.05 . This therefore suggests that we should reject our alternative hypothesis two $\left(\mathrm{Ho}_{2}\right)$ which states that management control does not significantly influence the capital projects execution of in public sector in Anambra State, Nigeria. 
The regression result shows that personnel control (PSC) has a positive and significant effect on the capital project execution in the state. The regression result also shows that management control (MGC) has a positive but insignificant effect on the capital project execution in Anambra state, Nigeria. The above finding is also in line with the findings of and Ishola, Abikoye and Olajide (2015), but negates the findings of Salifu (2015), Amudo and Inanga (2009).

\section{Conclusion and Recommendations}

From the analysis, the study revealed that personnel control (PSC) has a positive and significant effect on the capital project execution in Anambra state. The regression result shows that management control (MGC) has a positive but insignificant effect on the capital project execution in Anambra state, Nigeria. However, the capital project abandonment to be reduced, and high level of project execution to be recorded in State.

Based on the result, the researchers recommended that management control execution should be strengthened up in such regions as these were found to be positively and significantly affecting the rate of capital project execution in the state. Also Public sectors in the state, as well, the use internal control system to minimize the level of the neglected project in the state should be considered. 


\section{REFERENCES}

Abugri, S. S.(2015). Assessing the internal control systems of public institution: A case study of Tamale Polytechnic), A thesis submitted to Department of Accounting and Finance, Kwame Nkrumah University of Science and Technology School of Business, 1-75. Retrieved online at www.school of business KNUST.

Babatunde, S. A . \& Dandago, K. I.(2014). Internal control system deficiency and capital project mismanagement in the Nigeria public sector, Procedia social and Behavioural Science, 164. Available online @ www. Sciencedirect.com

Basak, G. B. (2010). Cost Management in an Imperfect World. Retrieved from http://www.docstoc.com

Basle Committee(1998). Framework for internal control systems in banking organizations

(September);1-29.

COSO(2013), Internal control framework, Retrieved online @www.pwc.com/us/en/forensicservics/publications/assets/pwc-new-internal-control-framework-litigation-counselperspective.

El- Rufai, N. (2012). The Tragedy of Abandoned Projects. Retrieved on December 8, 2013 from http://www.premiumtimeng.com/opinion.

Eniola, O.J. \& Akinselure, O.P.(2016). Effect of internal control on financial performance of firms in Nigeria(A study of selected manufacturing firms); IOSR Journal of Business and Management (IOSR-JBM). 18(10) (October.): 80-85

Www.iosrjournals.orgDOI:

ENSG (2010). Internal Control Manual for Enugu State Government, Retrieved online @ www. Enugu state 3_internal_control_manual...

Ezejiofor, R. A. \& Okolocha, C. B., (2020). Effect of internal audit function on financial performance of commercial banks in Nigeria. International Journal of Advanced Academic Research (Social and Management Sciences), 6(7); ISSN: 2488-9849 www.ijaar.org Journal DOI: 10.46654/ij.24889849 Article DOI: 10.46654/ij.24889849.s6723.

Frazer, L.(2016). An empirical analysis of the effect of internal control on deviation in small restaurants. Journal of behavioural studies in business, 10:1-11.

Hussaini, U. 1, \& Muhammed, U. D. (2018). The effect of internal control on performance of commercial banks in Nigeria. International Journal of Management Research \& Review. IJMRR/8(6)/13-32. ISSN: 2249-7196.

Ingwe, R., Mboto, W. A., \& Ebong, E. E. (2012). Project Abandonment, Corruption and Recovery of Unspent Budgeted Public Funds in Nigeria, Romanian Journal of Economics 1(34), 24-46.

Institute of Internal Auditors (IIA). (2012). International standards for the professional practice of internal auditing. 
Kabuye, F.(2019). Internal control systems, working capital management and financial performance of Supermarkets. Cognent Business \& Management Journal; 6(1): 164.

Nwachukwu C.C \& Emoli, F.(2011). Building construction project management success as a critical issues in Real Estate development and investment, American Journal of Social and Management Sciences, 2(1), 56-76.

Ofor, N.T.(2019). The internal control syetems in the public and private sectors.Association of National Accountants of Nigeria Mandatory Continuing Professional Development(MCPD) Programme,50-100.

Oyewobi, L. O., Ganiyu, B. O.,Oke, A. A., Olaawo, W., \& Shittu, A. A. (2011). Determinants of Unethical Performance in Nigerian Construction Industry, Journal of Sustainable Development, 4(4), 175-182.

Oraka, A. O., Erhirhie, F.E. Ezejiofor, R. A. (2018). Effect of Social and Environmental Audit in Contemporary Economy: Nigerian Experience. Journal for Studies in Management and Planning, 4(4) ISSN: 2395-0463 Available online: Available at http://edupediapublications.org/journals/index.php/JSMaP/

Salihu, A.M.(2015). Impact of internal audit unit in the effectiveness of internal control system of tertiary educational institutions in Adamawa State, Nigeria, International Journal of Humanities, Social Sciences and Education, 2 (5), 140-156.

Simon, L. (2012). Nigeria seeks to end curses of unfinished projects. Retrieved on October 20, 2013 from http://www.rnw.nt/africa/bulletin/nigeria.

Yousef, A. B. (2017). The impact of internal control requirements on profitability of Saudi shareholding companies,. https://doi.org/10.1108/IJCOMA-04-2013-0033

Zámečník, R. \& Zeman, V. (2007). The personnel controlling instrumentaria Human Resources Management \& Ergonomics 2/2007 